\author{
Jadwiga Waniakowa \\ Polska Akademia Nauk w Krakowie \\ Instytut Języka Polskiego \\ ORCID: 0000-0002-1651-1572; e-mail: jadwiga.waniakowa@ijp.pan.pl
}

\title{
Polskie słownictwo gwarowe w kontekście etymologicznym (na przykładzie nazw roślin)
}

\begin{abstract}
Abstrakt: W artykule przedstawiono problematykę słownictwa gwarowego z etymologicznego punktu widzenia. Zwrócono uwagę na konieczność badania leksyki gwarowej pod względem etymologicznym, wskazując na wieloaspektowe potrzeby w tym zakresie. Wszystkie prezentowane zagadnienia omówiono na przykładzie gwarowych nazw roślin, uwypuklając konieczność znajomości wszelkich cech botanicznych poszczególnych gatunków w celu ustalenia właściwej motywacji semantycznej nazw. Podkreślono, że w sferze etymologii gwarowych nazw roślin ogromnie ważne są nie tylko ich formy, ale też motywacja semantyczna i historia. To po ich zbadaniu (za pomocą metody historyczno-porównawczej) można wywodzić wnioski etymologiczne, gdzie kluczową rolę odgrywa końcowe stwierdzenie, czy dana nazwa gwarowa rośliny jest autentycznie gwarowa, czy jest odziedziczona lub zapożyczona. Stwierdzono ponadto, że metodologia etymologicznych badań gwarowych, oprócz zwykłych zasad stosowanych w dociekaniach etymologicznych, musi także brać pod uwagę wpływ realiów wiejskich, wierzeń, zwyczajów itd., innymi słowy, całokształtu kultury wiejskiej na motywację semantyczną słownictwa gwarowego. Stąd badania etymologiczne nad słownictwem gwarowym wymagają dużo bogatszego niż zazwyczaj warsztatu etymologicznego i dodatkowej wiedzy z zakresu dialektologii, historii kultury wiejskiej oraz etnologii.
\end{abstract}

Slowa kluczowe: słownictwo gwarowe, etymologia, gwarowe nazwy roślin, motywacja semantyczna.

\begin{abstract}
Polish dialectal vocabulary in an etymological context (the example of plant names). The article presents the issues of dialectal vocabulary from the etymological point of view. Attention has been drawn to the need of studying dialectal vocabulary with regard to the etymology, pointing to the multi-faceted requirements in this respect. All the presented issues have been discussed by using the example of dialectal plant names. Emphasis has been placed on the fact that one should know all the botanical features of individual species in order to determine the proper semantic motivation behind the names. It has been stressed that in the etymology of dialectal names of plants, not only their forms but also the semantic motivation and history are of extreme importance. After examining them (using the historical-comparative method), etymological conclusions can be drawn whether a given dialectal name of a plant is authentically dialectal, inherited or borrowed. Moreover, it has been found out that the methodology of etymological dialectal research, in addition to the typical principles used in etymological surveys, must take into account the influence of rural life, beliefs, customs, etc. In other words, the entire rural culture of the semantic motivation of the dialectal vocabulary needs to be considered. Hence, etymological research into dialectal vocabulary requires more sophisticated etymological techniques and additional knowledge of dialectology, history of rural culture and ethnology.
\end{abstract}

Keywords: dialectal vocabulary, etymology, dialectal plant names, semantic motivation. 
Polska leksykografia gwarowa jest wyjątkowo bogata. Jak wiadomo, prócz naukowych słowników gwarowych obejmujących cały polski obszar, istnieje bardzo dużo słowników regionalnych, a nawet takich, które gromadzą słownictwo tylko jednej wsi. Powstawały one i powstają od dawna. Część z nich to słowniki w pełni profesjonalne, tworzone przez językoznawców, część zaś stanowią słowniki opracowywane przez miłośników gwar, autochtonów, amatorów. Zrozumiałe zatem, że różnią się sposobem przedstawienia materiału leksykalnego i jego jakością, ale z pewnością mają jedną wspólną cechę: wszystkie służą ocaleniu wielowiekowego dziedzictwa użytkowników gwar, które obecnie coraz bardziej zanika. Jest to dziedzictwo nie tylko czysto leksykalne, ale przede wszystkim kulturowe. Przez materiał językowy z jego warstwą semantyczną przezierają bowiem realia wiejskie wraz z niesłychanie bogatą i zróżnicowaną sferą kulturową, obejmującą całokształt życia na wsi, z jego tradycjami, zwyczajami, wierzeniami itd.

Charakterystyczne, że miłośnicy swoich własnych gwar dość często interesują się nie tylko słownictwem, które chcą ocalić, ale też jego pochodzeniem. Są ciekawi „skąd się bierze" dany wyraz, skoro jest różny od tożsamego znaczeniowo wyrazu z języka ogólnopolskiego lub odnosi się do czegoś, co nie jest znane poza obszarem danej gwary czy dialektu. Niekiedy użytkownicy gwar sami usiłują dochodzić do etymologii poszczególnych słów, tłumacząc ich źródło i motywację na swój sposób, co często widzimy w dłuższych cytatach gwarowych ${ }^{1}$. Z drugiej strony, odtworzenie etymologii wyrazów gwarowych jest ogromnie ważne z językoznawczego punktu widzenia. Pochodzenie ukazuje bowiem najdawniejsze związki formalne i semantyczne słownictwa z rzeczywistością, odkrywa powiązania etniczne i kulturowe, przedstawiając przy tym pełnię procesów formalno-znaczeniowych, które zaszły w drodze tworzenia się danego leksemu, a następnie jego rodziny słowotwórczej. Etymologia wyrazów gwarowych jest konieczna, aczkolwiek niewidoczna, przy ustalaniu form haseł w naukowych słownikach gwarowych ${ }^{2}$. Na postawie dociekań etymologicznych leksykografowie „wyłuskują” z mnogości form tę, która w najwyższym stopniu odzwierciedla pochodzenie wyrazu, przy czym z reguły jest to postać zbliżona do literackiej, a ściślej takiej, która byłaby formą literacką danego wyrazu, gdyby istniał on w języku ogólnopolskim, zatem bez gwarowych cech fonetycznych i nawiązująca do źródłosłowu. W efekcie w naukowym słowniku gwarowym znajdujemy na przykład hasło chyżko z formą hyśko, hasło czwarzyć (się) z formami cwarzyć (się), ćvarzyć (sie), hasło dożreć (się) z formami doźreć, dorżeć itd. (SGP s.v. chyżko, czwarzyć [się], dożreć [się]), a nie odwrotnie. Ponadto to między innymi etymologia sprawia, że w słownikach gwarowych pojawiają się hasła homonimiczne ${ }^{4}$, por. np. I. BAŁUCH, II. BAŁUCH, I. CHOINKA,

${ }^{1} \mathrm{~W}$ polskiej literaturze językoznawczej zwrócił na to uwagę już dawno temu Cienkowski (1972), a po nim inni badacze.

${ }^{2}$ W większości naukowych słowników gwarowych postać wyrazów hasłowych jest zależna od ich etymologii, a właściwie etymologią generowana. Oczywiście nie można pominąć tu roli kategorii gramatycznych, części mowy, różnic paradygmatycznych itd., które także mają wpływ na formy wyrazów hasłowych.

${ }^{3} \mathrm{~W}$ zapisach gwarowych stosuję uproszczoną pisownię form.

${ }^{4}$ Obecność homonimów jest spowodowana oczywiście także względami gramatycznymi, które bardzo często decydują o liczbie haseł homonimicznych. 
II. CHOINKA, I. CZEPIĆ (SIĘ), II. CZEPIĆ (SIĘ) itd. (SGP s.v.) Z tego wynika, że dialektolodzy opracowujący słowniki gwarowe - nolens volens - muszą prowadzić studia etymologiczne, przynajmniej w ograniczonym zakresie.

Jak ogólnie wiadomo, etymologia, dział językoznawstwa diachronicznego, zajmuje się badaniem pochodzenia wyrazów. Istotę dociekań etymologicznych stanowi w równej mierze rekonstrukcja pierwotnej formy wyrazu, jego rdzenia, jak i jego pierwotnego, podstawowego znaczenia, czyli znaczenia etymologicznego. Można przytoczyć tu zdanie Wiesława Borysia, autora pierwszego - od czasów Aleksandra Brücknera - pełnego polskiego słownika etymologicznego:

Zadaniem badań etymologicznych jest odtworzenie pierwotnej motywacji wyrazu (wskazanie jego bezpośredniej podstawy derywacyjnej), wykrycie i objaśnienie jego struktury, wskazanie morfemów słowotwórczych oraz odtworzenie jego przypuszczalnego pierwotnego znaczenia i wyjaśnienie dalszego rozwoju semantycznego (Boryś 2005, 5).

Zatem przystępując do badania genezy jakiegoś leksemu, trzeba - jak wiadomo najpierw określić jego miejsce w systemie języka. Następnie analizuje się znaczenie wyrazu, jego stanowisko w danej grupie semantycznej oraz jego ewentualne synonimy i homonimy. Ważne jest także zbadanie zasięgu geograficznego oraz określenie ewentualnej rodziny wyrazowej. Wykrywa się wówczas, czy dany leksem jest izolowany, czy istnieją wyrazy mu pokrewne, czy jest żywym derywatem, czy jest wyrazem prymarnym, niepodzielnym słowotwórczo. Kolejny etap stanowi analiza historii wyrazu: poszukiwanie pierwszych poświadczeń i form, badania nad ciągłością rozwoju historycznego, ustalenie geografii historycznej (jeśli to możliwe) oraz objaśnienie historycznego rozwoju semantycznego (o czym dalej). Jak wiadomo, wywody etymologiczne opierają się na fonologii historycznej, leksykologii i gramatyce porównawczej (czyli na prawach głosowych) języków pokrewnych albo - przy zapożyczeniach - także na prawach głosowych języka, z którego dany leksem pochodzi. Etymolog musi się przy tym dobrze orientować w realiach kultury materialnej i duchowej społeczności, której słownictwo bada. Jednak pomimo spełnienia tych wszystkich wymagań, ustalenie pochodzenia danego wyrazu nie jest proste i dość często przybiera kształt kilku równie prawdopodobnych hipotez. Taka sytuacja jest spowodowana zwykle skromnym i niekompletnym materiałem językowym, który nie zawsze sprzyja wykryciu i objaśnieniu procesów, które zaszły w dawnych wiekach. Należy bowiem zaznaczyć, że etymologia jest dopiero wówczas wiarygodna, gdy wszystkie zmiany formalne od danej formy do zrekonstruowanej postaci pierwotnej dają się wytłumaczyć działaniem odpowiednich praw językowych, a zmiany znaczeniowe są logiczne i poparte paralelami semantycznymi. Jeśli zaś chodzi o stronę semantyczną analizy etymologicznej, to Franciszek Sławski twierdzi, że „za podstawowy cel etymologii należy [...] uważać rekonstrukcję motywacji" (Sławski 1998, 4). Chodzi oczywiście o odtworzenie motywacji semantycznej wyrazu. Do tego właśnie potrzebna jest wspomniana dogłębna znajomość realiów kulturowych. Szczególnie jest to ważne, gdy bada się pochodzenie słownictwa gwarowego, które ma ograniczony zasięg, bo zwykle używane jest w niewielkiej społeczności, a często wychodzi z użycia i nie jest znane młodszym pokoleniom, wiążąc się ściśle z dawnymi desygnatami, zwyczajami i wierzeniami, które odeszły już 
w przeszłość. Badacz pochodzenia słownictwa gwarowego nie tylko musi być zatem doskonale obeznany z szeroko pojętymi wiejskimi realiami, ale także powinien dobrze się orientować w historii kultury wiejskiej. Leksyka gwarowa jest również często poddana różnym wpływom obcym, tak w historii, jak współcześnie, i to innego rodzaju niż język ogólny, co także należy mieć na uwadze ${ }^{5}$. W gwarach bowiem mamy do czynienia z dużą liczbą zapożyczeń leksykalnych i kalk, zarówno historycznych, jak i współczesnych. Stąd w badaniach etymologicznych słownictwa gwarowego niezwykle ważne jest precyzyjne określenie geografii wyrazów, czyli ich miejsc występowania i zasięgów. Istotne jest także wyodrębnienie wszystkich przekształceń form obcych (adaptacji fonetycznych, morfologicznych itd.), które doprowadziły do powstania istniejących w gwarach postaci wyrazów zapożyczonych. Na koniec podkreślić wypada, że etymolog badający pochodzenie wyrazów gwarowych musi oczywiście znać świetnie system fonetyczny i morfologiczny danej gwary.

Jako ilustrację zasygnalizowanych zagadnień pragnę w niniejszym tekście omówić problemy pochodzenia polskich gwarowych nazw roślin. Jest to słownictwo szczególnego rodzaju. Do wymienionych problemów należy w tym wypadku dodać jeszcze szereg innych, właściwych dla gwarowego nazewnictwa roślin. W związku z tym, że w Polsce jest to słownictwo zanikające, a $z$ drugiej strony w pewnym stopniu specjalistyczne, należy przed przystąpieniem do badań nad jego pochodzeniem rozstrzygnąć sporo podstawowych dla wiarygodności materiału kwestii. Kluczowa dla gwarowych nazw roślin jest identyfikacja, to jest przyporządkowanie nazwy odpowiedniemu gatunkowi botanicznemu (zarówno w historii, jak i współcześnie). Problem ten, sam w sobie skomplikowany, wiąże się ściśle z polisemią i homonimią gwarowych nazw z tej dziedziny. Inne, nie mniej istotne, zagadnienia to - wspominana już - motywacja semantyczna i - wreszcie - poprawność zapisów gwarowych.

Przyporządkowanie nazwom odpowiednich gatunków roślin jest najistotniejsze, od tego bowiem zależy wiarygodność dalszych wywodów ${ }^{6}$. W źródłach gwarowych mamy często do czynienia z nieprecyzyjną definicją, która nie wskazuje, o który gatunek, a nawet rodzaj chodzi. Czasem niektóre źródła gwarowe jako nazwę identyfikacyjną podają inną nazwę gwarową rośliny lub nazwę potoczną, która może się odnosić do co najmniej dwóch (lub nawet kilku) rodzajów lub gatunków roślin. Wiele źródeł podaje tylko opis, do czego była stosowana roślina o danej nazwie gwarowej lub jak ta roślina wygląda i gdzie rośnie. W takich wypadkach w oparciu o opracowania botaniczne i zielarskie można próbować dociekać, o który gatunek chodzi. Zwykle zatem przyporządkowanie poświadczonej gwarowej nazwy danemu gatunkowi rośliny wymaga sporo intuicji, logiki i kojarzenia różnych faktów: historycznojęzykowych, porównawczo-językowych, historycznokulturowych oraz botanicznych. Mimo to jednak wiele materiału należy wycofać, ponieważ nie da się go prawidłowo zidentyfikować (więcej: Waniakowa 2012, 38, 41). Właściwe rozpoznanie polega na przypisaniu nazwie gwarowej odpowiedniej polskiej nazwy naukowej gatunku (razem z ewentualnymi synonimami)

\footnotetext{
5 Są to na ogół wpływy gwar języków ościennych, nie języków literackich. Stąd problem źródeł obcych dodatkowo komplikuje odtworzenie procesów, które kształtowały daną formę w polskich gwarach.

${ }^{6}$ Problemem tym zajmowałam się bardziej szczegółowo wcześniej (por. np. Waniakowa 2012, 35-42; 2017), zatem nie będę tu go szerzej rozwijała (por. na ten temat też Wróbel 2004, 66).
} 
oraz naukowej nazwy łacińskiej wraz z odnośnikiem do nazwiska jej autora (a także $\mathrm{z}$ ewentualnymi synonimami), np. pol. gw. plucne ziele 'miodunka plamista, syn. miodunka lekarska, Pulmonaria officinalis L.' Jest to także konieczne w dalszych badaniach historyczno-porównawczych $\mathrm{i}$ w późniejszym porównywaniu $\mathrm{z}$ nazwami $\mathrm{z}$ innych języków.

Niezwykle istotnym problemem w ustalaniu pochodzenia gwarowych nazw roślin jest - wspomniana już - ich motywacja semantyczna. Najczęściej przyjmuje się, że W procesie nominacji działają następujące mechanizmy motywacyjne: wygląd rośliny, miejsce występowania, właściwości (faktyczne, np. lecznicze, i przypisywane - wiążące się $\mathrm{z}$ wierzeniami i legendami), przeznaczenie (także to związane $\mathrm{z}$ określonymi zwyczajami w danej społeczności wiejskiej) oraz inne specyficzne dla danego rodzaju czy gatunku. Każdy z tych czynników ma wpływ na zawartość treściową nazw. Oczywiste, że każda z tych ogólnych motywacji rozkłada się na szereg motywacji szczegółowych. O podziałach nazw roślin ze względu na motywację pisano sporo (m. in. Pawłowski 1974, 163-169, Tokarski 1993, 340-341, Pelcowa 2001, 100, Waniakowa 2012, 63-68), podobnie o podstawowej roli motywacji semantycznej nazw roślin w ustalaniu ich etymologii (por. np. Dębowiak, Waniakowa 2019, 173-200).

Innym, również ważnym, problemem są liczne drukarskie błędy w dawnych źródłach gwarowych zawierających nazwy roślin. W takich przypadkach trudno stwierdzić, czy dziwny zapis oddaje rzeczywiste brzmienie nazwy, czy jest to tylko przekręcenie spowodowane pomyłką typograficzną. Warto zauważyć, że część źródeł zawierających gwarowe nazwy roślin podaje zapisy fonetyczne lub półfonetyczne, odzwierciedlające w zamierzeniu autorów postaci brzmieniowe nazw, inne źródła podają nazwy „odtworzone" na podstawie brzmienia gwarowego, czyli w formie takiej, jaka istniałaby w języku ogólnym, a jeszcze inne w ogóle nie dostrzegają tego problemu i stosują wszelkie zapisy: fonetyczne, półfonetyczne oraz sprowadzone do języka ogólnego. Bardzo trudno jest w takich wypadkach ustalić faktyczne formy nazw (por. Waniakowa 2012, 42; 2015, 291).

Przy segregowaniu materiału gwarowego z zakresu nazw roślin obserwuje się zjawiska polisemii i homonimii. Widoczna jest wielość nazw dla jednego rodzaju bądź gatunku roślin, z drugiej strony zaś jedna nazwa może się odnosić do wielu rodzajów lub gatunków roślin. Oba te zjawiska, wynikające każdorazowo z motywacji semantycznej (por. wyżej), stanowią poważne utrudnienie w badaniu nazw gwarowych, zwłaszcza w analizie historyczno-porównawczej i etymologicznej. Nie można bowiem nigdy kierować się jedynie formą nazwy przy poszukiwaniach w źródłach i literaturze, trzeba zawsze się upewnić, że chodzi o właściwy, interesujący nas gatunek rośliny (por. Waniakowa 2015, 291).

Poprawnie zidentyfikowany, odpowiednio objaśniony semantycznie i właściwie zapisany materiał należy następnie porównać z materiałem leksykalnym obecnym w historycznych i współczesnych słownikach języka polskiego, poczynając od SStp i SP XVI. Trzeba także przeprowadzić poszukiwania w dawnych polskich zielnikach,

\footnotetext{
7 Taką motywację może stanowić na przykład pochodzenie rośliny. Widoczne to jest chociażby w nazwach tataraku zwyczajnego, Acorus calamus L.: tatarski korzeń, tatarczuk, tatar i inne, a także nazwa ogólnopolska, tatarak.
} 
wychodząc od dzieła Jana Stanki (1472) i herbarzy XVI-wiecznych, jak np. Falimirza (1534), Spiczyńskiego (1542) czy Siennika (1568), przez późniejsze, jak Syreniusza (1613), po specjalistyczne opracowania, które dotyczą dawnych polskich nazw roślin, jak np. SN, Symb. i monografia Anny Spólnik (1990). Takie postępowanie jest nieodzowne, by skonstatować, czy mamy do czynienia z nazwami zakorzenionymi od dawna, być może od początku, w języku polskim, czy też z nazwami używanymi jedynie w gwarach. Zdarza się, że napotykamy warianty formalne nazw lub stwierdzamy, że dana nazwa odnosiła się w przeszłości do innego gatunku czy nawet rodzaju. Tego typu spostrzeżenia są niezwykle istotne jako przygotowanie do dalszych etapów pracy (por. Waniakowa 2015, 291-292).

Następną fazą badań historyczno-porównawczych jest konfrontacja z nazewnictwem botanicznym w językach słowiańskich, z uwzględnieniem zwłaszcza nazw gwarowych w poszczególnych językach. Badacz powinien czerpać ze słowników historycznych i współczesnych języków słowiańskich, słowników gwarowych (w tym z licznych słowników nazw roślin w wielu językach), atlasów językowych i opracowań specjalistycznych - zarówno językoznawczych (w tym przede wszystkim etymologicznych), jak i botanicznych. Literatura tego obszaru jest tak olbrzymia, że nie sposób tutaj choćby pobieżnie wymienić tytuły i autorów, ale jedynie korzystanie z niej zapewnia odpowiedni materiał porównawczy dla polskich nazw gwarowych. Przeprowadziwszy studia komparatystyczne w zakresie słowiańskich nazw roślin (w tym historycznych i gwarowych), można stwierdzić, czy badane polskie nazwy gwarowe mają nawiązania słowiańskie, czy są polskimi formami rodzimymi lub nawet autentycznymi wytworami użytkowników tutejszych gwar. Jeśli mają odpowiedniki w językach słowiańskich (choćby w jednym z nich), można już na tym etapie sporo powiedzieć o zasięgu geograficznym nazw i ich dziejach (por. Waniakowa 2015, 292).

Idąc w porównaniach dalej poza Słowiańszczyznę, widzimy, że wiele słowiańskich nazw roślin, w tym polskich i przede wszystkim polskich gwarowych, ma odpowiedniki semantyczne w innych językach europejskich. Aby to udokumentować, etymolog musi sięgnąć do opracowań i słowników języków niesłowiańskich, przede wszystkim niemieckich i łacińskich, ale także francuskich i greckich, jak np. Marzell (2000), André (1956), Genaust (2005). Tak skonfrontowany materiał może być podstawą głębszych analiz oraz pozwala na wyciąganie właściwych, odpowiednio umocowanych dokumentacyjnie wniosków co do pochodzenia polskich nazw gwarowych roślin (por. Waniakowa 2015, 292).

Przedstawiłam jedynie schemat postępowania przy dociekaniu pochodzenia gwarowych nazw roślin. Warto jednak pamiętać, że do każdej należy podejść indywidualnie i szczegółowo rozpatrywać wszystkie specyficzne cechy i warunki, jakie jej dotyczą. W badaniu genezy nazw za każdym razem inny czynnik może okazać się kluczowy.

Stosując omówione metody i postępując według prawideł warsztatu etymologicznego, można wśród gwarowych nazw roślin wyróżnić te odziedziczone, na które składają się nazwy rodzime, stare zapożyczenia i stare kalki, oraz nazwy ogólnopolskie, które są obecne także w gwarach, nazwy autentycznie gwarowe, faktycznie powstałe na polskim gruncie gwarowym, to jest będące wytworem inwencji użytkowników gwar, nowe kalki i nowe zapożyczenia. Przy nazwach odziedziczonych najważniejsza okazuje się ich historia i dotarcie do pierwszych poświadczeń. Przy nazwach rodzimych ważne 
jest ścisłe rozdzielenie, czy mają one rodowód prasłowiański lub jeszcze wcześniejszy, czy sięgają tylko staropolszczyzny. Przy starych zapożyczeniach istotne jest, kiedy i z jakiego języka zostały przejęte przez dawną polszczyznę. Przy starych kalkach niezmiernie ważne jest odkrycie nie tylko najwcześniejszych poświadczeń, ale także wykazanie, że w innych językach $\mathrm{i}$ ich historii mamy do czynienia $\mathrm{z}$ tym samym modelem semantycznym, który wywodzi się najczęściej od dawnych (średniowiecznych i starożytnych) łacińskich i greckich nazw roślin. Tylko porównywanie historycznych nazw roślin w językach europejskich uprawnia do stwierdzenia, że dana nazwa jest starą kalką. Wbrew pozorom, takich kalk wśród polskich gwarowych nazw roślin jest całkiem dużo (por. Waniakowa 2012, 174-185). Stosunkowo najmniej interesujące są ogólnopolskie nazwy roślin, które są używane także w gwarach. Bardzo ciekawe są natomiast nazwy roślin autentycznie gwarowe. Przy nich najważniejsze jest odkrycie właściwej motywacji semantycznej, co najczęściej wiąże się z bogatą sferą kulturową wsi, ze zwyczajami i wierzeniami, w tym wiarą w magiczne właściwości roślin. Tego rodzaju nazwy są często metaforami. Odkrycie ich podstaw i mechanizmu powstawania wymaga od badacza - etymologa, dialektologa i kulturoznawcy zarazem - dogłębnej znajomości szeroko pojętej kultury (i jej historii) danej społeczności wiejskiej. Wymaga doskonałej znajomości tradycji i uwarunkowań religijnych. Przy nazwach będących nowymi zapożyczeniami największą rolę odgrywa zasięg geograficzny w połączeniu ze wskazaniem podstawy zapożyczenia w języku ościennym lub jego gwarach. Przy nowych kalkach istotny jest nie tylko ich zasięg geograficzny, ale także wykazanie tożsamości semantycznej danych nazw z nazwami roślin w językach ościennych lub w gwarach tych języków.

Szczególnie cenne okazuje się odkrywanie w ten sposób starych i nowych kalk wśród gwarowych nazw roślin. Przy podejściu wyłącznie synchronicznym robią one bowiem wrażenie nazw rodzimych, a nawet autentycznie gwarowych, ponieważ nie różnią się od nich ani formalnie, ani znaczeniowo, gdy tymczasem ich tradycja jest długa i bogata, a zasięg szeroki, ponieważ mają odpowiedniki - poza Słowiańszczyzną - także w wielu językach niesłowiańskich, a ich korzenie sięgają średniowiecza, a niekiedy starożytności.

Opisany w niniejszym tekście sposób historyczno-porównawczego badania gwarowych nazw roślin sprawdza się oczywiście nie tylko w odniesieniu do polskiego materiału gwarowego, ale także w zakresie gwarowych nazw roślin innych języków słowiańskich i w ogóle europejskich, co można stwierdzić, biorąc pod uwagę liczne odpowiedniki formalne i semantyczne nazw polskich. Co więcej, uwidacznia się przy tego rodzaju analizach wspólnota kultury europejskiej, która datuje się od starożytności i średniowiecza. Warto zwrócić uwagę, że do tej wspólnoty należą także kultura i tradycje użytkowników gwar polskich. $Z$ zebranych tu rozważań ponadto wynika, że językoznawca, zajmujący się gwarowymi nazwami roślin w ujęciu historyczno-porównawczym, musi być zarówno etymologiem, jak i dialektologiem oraz kulturoznawcą, który dodatkowo dysponuje sporą wiedzą botaniczną.

Trzeba zatem na koniec jeszcze raz podkreślić, że w sferze etymologii gwarowych nazw roślin ogromnie ważne są nie tylko ich formy, ale też motywacja semantyczna i historia. To po ich zbadaniu (za pomocą metody historyczno-porównawczej) można wywodzić wnioski etymologiczne, gdzie kluczową rolę odgrywa końcowe 
stwierdzenie, czy dana nazwa gwarowa rośliny jest autentycznie gwarowa, czy jest odziedziczona lub zapożyczona. Ponadto niezwykle istotne jest, że metodologia etymologicznych badań gwarowych, oprócz zwykłych zasad stosowanych w dociekaniach etymologicznych, musi obejmować wpływ realiów wiejskich, tradycji, wierzeń, zwyczajów itd., innymi słowy, całokształtu kultury wiejskiej na motywację semantyczną słownictwa gwarowego. Stąd badania etymologiczne nad słownictwem gwarowym wymagają od badaczy dużo bogatszego warsztatu etymologicznego i dodatkowej wiedzy z zakresu dialektologii, historii kultury wiejskiej oraz etnologii.

\section{Literatura}

André J. (1956), Lexique des termes de botanique en latin, Paris.

Boryś W. (2005), Słownik etymologiczny języka polskiego, Kraków.

Cienkowski W. (1972), Teoria etymologii ludowej, Warszawa.

Dębowiak P., Waniakowa J. (2019), Semantic Motivation of Plant Names as Part of their Etymology, [w:] The Landscape of Lexicography, eds A. Villalva, G. Williams, Lisboa, s. 173-200.

Falimirz S. (1534), O ziołach i mocy jich, Kraków.

Genaust H. (2005), Etymologisches Wörterbuch der botanischen Pflanzennamen, Dritte, vollständig überarbeitete und erweiterte Ausgabe, Hamburg.

Marzell H. (2000), Wörterbuch der deutschen Pflanzennamen, t. I-V, Fotomechanischer Nachdruck der Erstausgabe 1943-1958, Köln.

Pawłowski E. (1974), Polskie nazwy roślin. (Próba klasyfikacji semantycznej), [w:] Studia indoeuropejskie, red. J. Kuryłowicz, Prace Komisji Językoznawstwa, t. 37, Wrocław -, s. $163-169$.

Pelcowa H. (2001), Interferencje leksykalne w gwarach Lubelszczyzny, Lublin.

SGP, Słownik gwar polskich, opr. przez Pracownię Dialektologii Polskiej (dawniej Zakład Dialektologii Polskiej) Instytutu Języka Polskiego PAN w Krakowie, red. M. Karaś, S. Urbańczyk, J. Reichan, J. Okoniowa, B. Grabka, R. Kucharzyk, Wrocław - Kraków -, 1979-.

Siennik M. (1568), Herbarz, to iest zioł tutecznych, postronnych i zamorskich opisanie [...], Kraków.

Sławski F. (1998), Pięćdziesiąt lat nad etymologia, „Rocznik Slawistyczny”, LI, s. 3-5.

SN, Majewski E., Słownik nazwisk zoologicznych i botanicznych polskich [...], t. I-II, Warszawa 1889-1898.

SP XVI, Stownik polszczyzny XVI wieku, red. M.R. Mayenowa, Wrocław -, 1966-.

Spiczyński H. (1542), O ziołach tutecznych i zamorskich i mocy ich, Kraków.

Spólnik A. (1990), Nazwy polskich roślin do XVIII wieku, Prace Komisji Językoznawstwa PAN w Krakowie, nr 58, Wrocław -.

SStp., Stownik staropolski, red. S. Urbańczyk, t. I-XI, Wrocław 1953-2002.

Stanko J. (1472), Antibolomenum Benedicti Parthi [rękopis przechowywany w Bibliotece Krakowskiej Kapituły Katedralnej, nr Ms 225].

Symb., J. Rostafiński, Symbola ad historiam naturalem medii aevi [...], t. I-II, Cracoviae 1900. 
Syrenius S., (1613), Zielnik herbarzem z ięzyka Łacińskiego zowia [...], Kraków.

Tokarski R. (1993), Stownictwo jako interpretacja świata, [w:] Encyklopedia kultury polskiej XX wieku, t. II: Współczesny język polski, red. J. Bartmiński, Wrocław, s. 335-362.

Waniakowa J. (2012), Polskie gwarowe nazwy dziko rosnacych roślin zielnych na tle stowiańskim. Zagadnienia ogólne, Kraków.

Waniakowa J. (2015), Jak badać pochodzenie i historię gwarowych nazw roślin?, „Biuletyn Polskiego Towarzystwa Językoznawczego", LXXI, s. 289-298.

Waniakowa J. (2017), The problem of plant identification in etymological research on Slavic phytonymy, [w:] Etymological research into Czech. Proceedings of the Etymological Symposium Brno 2017, 12-14 September, Studia etymologica Brunensia, vol. 22, red. I. Janyškova, H. Karlikova, V. Boček, Praha, s. 459-470.

Wróbel H. (2004), Związki staroczesko-staropolskie w terminologii botanicznej, Kraków [przedruk z: Zeszyty Naukowe Wyższej Szkoły Pedagogicznej w Katowicach, Prace Katedry Języka Polskiego II, Katowice 1962, s. 105-137]. 